トピックス

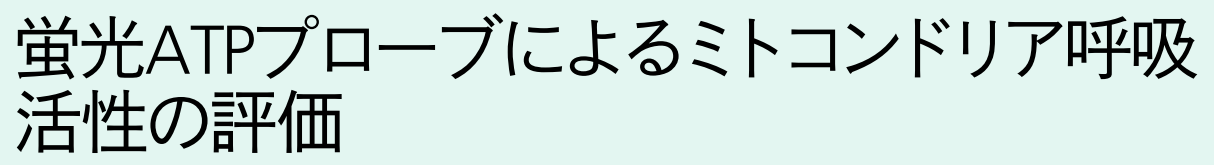

\author{
小柴玩己九州大学大学院理学研究院 \\ 今村博臣 京都大学大学院生命科学研究科
}

\section{1. | はじめに}

ミトコンドリアは，真核細胞内に広く存在する細胞 小器官の一つであり，これまでに代謝や細胞死（アポ トーシス）などにまつわる多くの研究が行われてき た. 一般に，ミトコンドリアは細胞内におけるエネル ギ一産生工場とも呼ばれ，その機能発現はユニークな 二重の膜構造（外膜と内膜）と核染色体とは異なる独 自のゲノム（ミトコンドリア DNA:mtDNA）の存在に よってもたらされる ${ }^{1)}$. ヒトの mtDNA は, 約 16,500 塩基対からなり，その遺伝情報はミトコンドリア呼吸 活性に必須の電子伝達系タンパク質群のらちで 13 種 類の構成サブュニットをコードしている. ミトコンド リアの呼吸活性に伴った酸化的リン酸化より造り出さ れるアデノシン三リン酸（ATP）は，生体内で消費さ れる大部分のエネルギー源として利用されていること からも，ミトコンドリアは生命機能の根幹を支えてい ると言える. 近年, 著者（今村）が中心となり開発し た蛍光 ATP バイオセンサーによって生きた細胞内で の ATP 動態を可視化することが可能となり，その結 果, 培養細胞や個体内に打けるATP の濃度変化を高 い精度で解析することが可能になった ${ }^{2), 3)}$.

\section{2. 培養細胞内での ATP イメージング}

私たちが動物細胞を用いて実験を行ら際に，その培 養に使用する培地はグルコースを主な炭素源とするこ とが一般的である。実際に，グルコースを含む培地を 用いることで細胞内におけるエネルギ一代謝は好気的 条件下に打いても解糖系に依存した状態になることが 知られており (好気的解糖), 癌由来の細胞などはそ の顕著なケースと言える ${ }^{4)}$ ，好気的解糖に依存した細 胞では，そのエネルギー産生効率は非常に悪く，また 大量のグルコースを消費してターンオーバーの速い ATP 産生を行っている。本稿では，培養細胞内におけ
るエネルギー産生とミトコンドリアの寄与について考 察したい。

まず初めに筆者らは，哺乳動物細胞内におけるミ トコンドリア依存によるATP 産生条件を調べる目的 で，実験に用いる培地中の炭素源をグルコースとガ ラクトース（ルロワール経路を介した解糖中間体の 獲得）に限定した二種類の培地を準備し，それぞれ の培地下にて培養した細胞内エネルギ一代謝をライブ で解析した，具体的には，蛍光 ATP バイオセンサー (ATeam 1.03; 図 1A） ${ }^{2)}$ を恒常発現させたヒト腎蔵由来 培養細胞（HEK293）を，上記のグルコース及びガラ クトース含有培地下で培養し，それぞれの細胞内 ATP 濃度をイメージングした. グルコース，及びガラク トース含有の条件共に, 細胞内には十分量の ATPを 反映した蛍光共鳴エネルギー移動（FRET）が観察さ れた ${ }^{5)}$ (図 1B). 次に, これら培湌条件下に颃いて トコンドリア呼吸鎖複合体 I の阻害剂であるロテノン を添加し，その後の FRET 変化をモニターした。 その 結果, グルコース含有培地においてはロテノン添加後 にもかかわらず十分な ATP 濃度を示す FRET 変化が 観察された一方で，ガラクトースを含む培地下では口 テノン添加に伴い劇的な ATP 濃度の減少が確認され た（図 1B; 右の写真)。この結果は,グルコースを栄 養源として培養した細胞内では，ATP産生がミトコン ドリアの呼吸活性にほとんど依存せず，ほぼ解糖系に より得られたATP産生であったことを示している. 一方で，ガラクトース培地下では，解糖系以降のミト コンドリア内に括ける酸化的リン酸化に依存した ATP 産生が主に行われ，その後のロテノンの添加はその生 理活性を阻害したことを表していたものと思われた。 この結果から, ガラクトース培地下においては, 細胞 内のエネルギー供給が解糖系のみでは不十分で，結果 として効率の良いミトコンドリアに依存したATP 産 生に転換したことが予想された. 
A

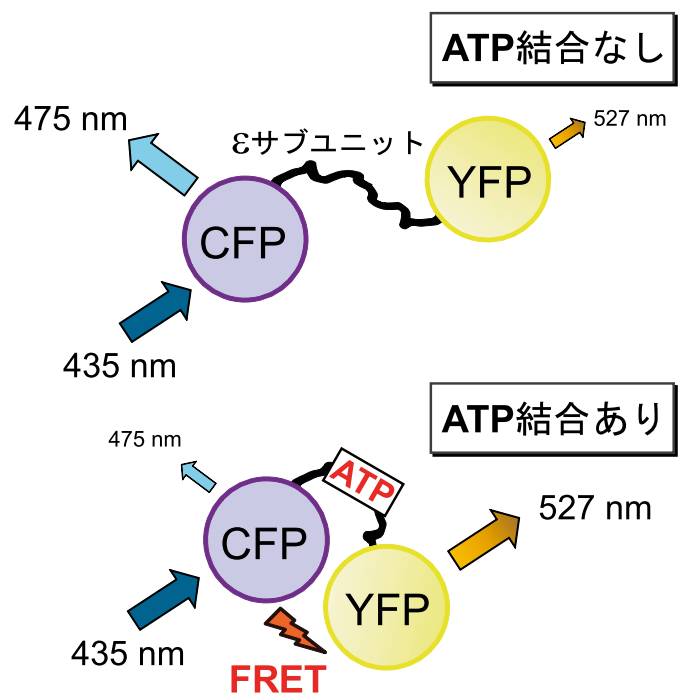

B

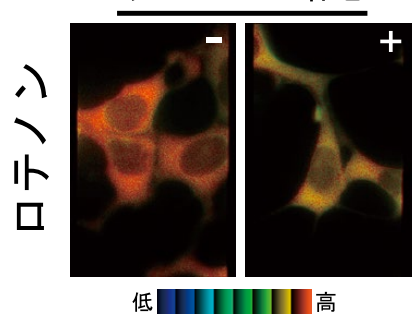

ATP濃度

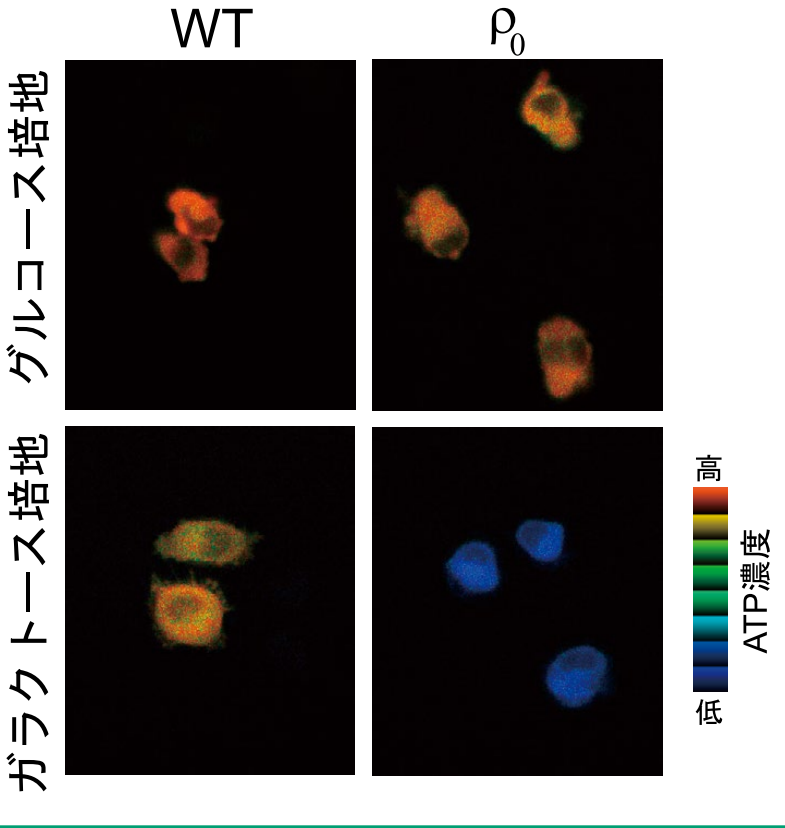

図 2

$\rho_{0}$ 細胞を用いた ATP イメージング解析. $\rho_{0}$ 細胞，及びその親株 (WT) にATeam1.03を一過性発現させ, 炭素源の異なる培地を用い て培養した. 右側の $\rho_{0}$ 細胞では, ガラクトース培地下でATP 量が 枯渇している様子が観察された. 写真は文献 5 を一部改変し転載.

測定より，両細胞共にATP 濃度が高い状態に保たれ ていることが示された ${ }^{5)}$ (図 2; 上段の写真).そこで, これら細胞株の培養条件をミトコンドリア依存のガラ クトース培地にシフトすると, $\rho_{0}$ 細胞でのみ ATP 濃 度の枯渴が観察された（図 2 ; 右下の写真）。この結果 より， $\rho_{0}$ 細胞では予想通りに解糖系依存のエネルギー 供給が行われていることが確認できた。

\section{4. ミトコンドリア病関連変異と ATP 産生}

最後に，筆者らは本法をミトコンドリア病との関連 がある mtDNA 変異株（サイブリッド）を用いて ATP のイメージング解析を行った．実験では，レーベル遺 伝性視神経症（LHON）の発症に関連する mtDNA変 異 $(\mathrm{ND} 1$; 呼吸鎖複合体 I の機能不全）と，ミトコン ドリア脳笳症関連の変異 $(\mathrm{COX}$; 呼吸鎖複合体 IV の 機能不全）をそれぞれに有した二種類のサイブリッ ド7),8）を用いた。 ND1 及びCOXサイブリッド共に, 呼吸鎖複合体を構成する一部のサブュニットに点変異 による機能障害が生じるために正常な酸化的リン酸化 が行えず，ガラクトース培地下ではATP 濃度が著し く低下している様子が確認できた（図 3; 中列の写真). 特筆すべきは，ND1 サイブリッドに㧧いて，ガラク トース培地中に呼吸鎖複合体 II の基質であるコハク 酸を添加することで細胞内の ATP 濃度が回復した点 である (ND1; +コハク酸)。この結果は，コハク酸 


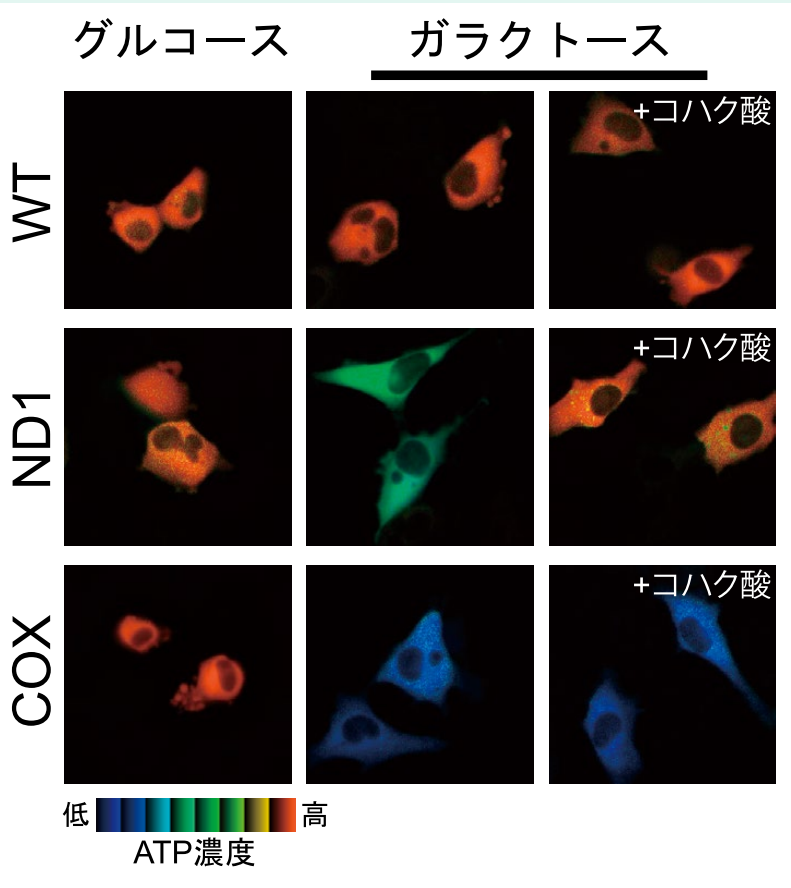

図 3

mtDNA 変異によるATP 産生の検証実験. ミトコンドリア病関連 の mtDNA 変異 (ND1 及び COX) サイブリッドとその親株 (WT) にそれぞれ ATeam 1.03 を一過的に発現させ, ATP イメージングを 行った様子. ガラクトース培地中にコハク酸を添加した実験で は, ND1 サイブリッドにおいて ATP 量の回復が観察された（右 側)。写真は文献 5 を一部改変し転載.

の添加により ND1 サイブリッドの障害を受けた呼吸 鎖複合体 I をバイパスし，複合体 II 以降の機能立進に 伴らATP産生が行われたことを示している. 事実, 複合体 IV の機能不全変異体（COX）ではコハク酸添 加にもかかわらずATP 産生能の回復は見られなかっ た (COX; +コハク酸).

5. まとめ

本実験では，ミトコンドリア機能障害をもたらす 様々な細胞株や薬剂を用いてATPイメージング解析を 行い，細胞内におけるミトコンドリアに依存したエネ ルギー代謝の動的な振る舞いを明らかにすることがで きた. ミトコンドリアは近年の研究から，エネルギー 産生以外の更なる役割も明らかになっている ${ }^{9,10)}$ 。し かしながら，そのよらな新たな役割も間接的にはエネ ルギー代謝と繋がっていることは十分に予想され，こ のようなATP イメージング解析とのコラボレーショ ンにより今後の更なる理解の進展が期待できる.

\section{謝 辞}

本稿で紹介したATPイメージングの解析は，九州 大学大学院生・吉住拓馬氏（学振特別研究員）により

行われた成果です， $\rho_{0}$ 細胞，及び $\mathrm{mtDNA}$ 変異サイブ リッドは筑波大学・中田和人教授と海外研究協力者ら よりそれぞれ分与頂いた。 長崎大学・稲岡健ダニエル 博士には御多忙の中, 本稿の推敲を快く御引き受け 頂き，貴重なコメントを頂戴しました．最後に，本 研究は科学研究費補助金（研究課題番号; JP26291032, JP17H03667)，ライフサイエンス振興財団，ノバル ティス科学振興財団，及び株式会社カネカの御援助に より行われており，ここに併せて感謝申し上げます。

文 献

1) Attardi, G., Schatz, G. (1988) Annu. Rev. Cell Biol. 4, 289-333. DOI: 10.1146/annurev.cb.04.110188.001445.

2) Imamura, H. et al. (2009) Proc. Natl. Acad. Sci. USA 106, 1565115656. DOI: $10.1073 /$ pnas.0904764106.

3) Tsuyama, T. et al. (2013) Anal. Chem. 85, 7889-7896. DOI: $10.1021 / \mathrm{ac} 4015325$.

4) Rossignol, R. et al. (2004) Cancer Res. 64, 985-993. DOI: 10.1158/0008-5472.can-03-110.

5) Yoshizumi, T. et al. (2017) Sci. Rep. 7, 5379. DOI: 10.1038/ s41598-017-05808-w.

6) King, M. P., Attardi, G. (1996) Methods Enzymol. 264, 304-313. DOI: $10.1016 / S 0076-6879$ (96) 64029-4.

7) Baracca, A. et al. (2005) Arch. Neurol. 62, 730-736. DOI: 10.1001/ archneur.62.5.730.

8) D'Aurelio, M. et al. (2006) Hum. Mol. Genet. 15, 2157-2169. DOI: $10.1093 / \mathrm{hmg} / \mathrm{ddl} 141$.

9) McBride, H. M. et al. (2006) Curr. Biol. 16, R551-R560. DOI: 10.1016/j.cub.2006.06.054.

10) Koshiba, T. (2013) Biochim. Biophys. Acta 1833, 225-232. DOI: 10.1016/j.bbamcr.2012.03.005.

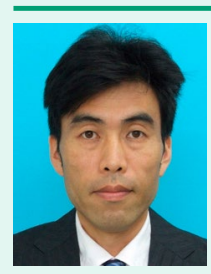

小柴玩己

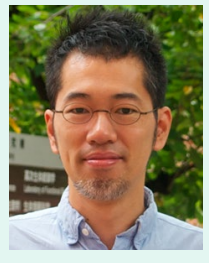

今村博臣

\section{小柴玩己（こしば たくみ）}

九州大学大学院理学研究院准教授

2001 年北海道大学大学院理学研究科修了博士 (理 学). 00-02 年日本学術振興会特別研究員, 01-05 年カリフォルニア工科大学博士研究員, 05 年九 州大学大学院理学研究院助教授, 07 年より現職. 12 年文部科学大臣表彰若手科学者賞, 第 14 回花 王研究奨励賞, 及び日本生化学会奨励賞を受賞. 研究内容: ミトコンドリア・ダイナミクスとその 生理機能解析

連絡先: 7 819-0395 福岡市西区元岡 744 E-mail: koshiba.takumi.688@m.kyushu-u.ac.jp URL: http://www.biology.kyushu-u.ac.jp/ koshiba/ index.html

\section{今村博臣（いまむら ひろみ）}

\section{京都大学大学院生命科学研究科准教授}

2002 年東京大学大学院農学生命科学研究科修了 博士 (理学). 02-06 年 JST ERATO 吉田 ATP シス テムプロジェクト研究員, 06-07 年日本学術振興 会特別研究員, 07-11 年 JST さきがけ研究者, 11-15 年京都大学白眉センター特定准教授, 15 年より現職. 07 年日本生物物理学会若手奨励賞, 16 年長瀬研究振興賞を受賞. 研究内容:細胞内代謝をイメージングする蛍光バ イオセンサーの開発 